\title{
METHODOLOGY OF MODELLING SIMULATION OF URBAN SCENARIOS
}

\author{
METODOLOGIA DE MODELAGEM: \\ SIMULAÇÃO DE CENÁRIOS URBANOS
}

Roberta Plangg Riegel roplangg@yahoo.com.br

Doutora em Qualidade Ambiental na Universidade Feevale (Novo Hamburgo/Brasil).

Darlan Daniel Alves darlandaniel@gmail.com

Doutor em Qualidade Ambiental na Universidade Feevale (Novo Hamburgo/Brasil).

Leonardo Espíndola Birlem leonardobirlem@gmail.com

Graduando em Engenharia Química na Universidade Feevale (Novo Hamburgo/Brasil).

\section{Bruna Schmidt brunacschmidt@hotmail.com}

Graduanda em Engenharia Civil na Universidade Feevale (Novo Hamburgo/Brasil).

Marco Antônio Siqueira Rodrigues marcor@feevale.br

Doutor em Ciênicas dos Materiais pela Universidade Federal do

Rio Grande do Sul (Porto Alegre/Brasil).

Professor na Universidade Feevale (Novo Hamburgo/Brasil).

Daniela Muller de Quevedodanielamq@feevale.br

Doutora em Recursos Hídricos e Saneamento Ambiental pela

Universidade Federal do Rio Grande do Sul (Porto Alegre/Brasil).

Professora na Universidade Feevale (Novo Hamburgo/Brasil). 


\section{ABSTRACT}

Urbanization has led to a series of problems in medium and large cities, resulting from a lack of planning and technologies to support decision making. This work aims to contribute to the methodology of modeling by cellular automata, aiming the study of the processes that condition the expansion of the urban area. Having as a study case of the municipality of Novo Hamburgo, RS, Brazil. For this purpose, the urban areas of 1967, 1977, 1987, 1997, 2009 and 2015 were used, totalling a historical analysis of 48 years, besides the thematic maps: Declivities, Hypsometric, Land Use, Water Resources and Road System. The compiled data was inserted in the environment of the platform Dinamica EGO, which is a free software that uses the system of Cellular Automata. The software employs a set of input maps composed of an initial landscape, a final landscape and a compilation of thematic variables that are combined from the definition of weights of evidence to generate the transition probability maps. The results showed similarity indexes of 0.9 for the first three models, 1977, 1987 and 1997, as well as 0.83 for the simulation of 2015. It was also possible to analyze the predominant factors for each expansion process, besides the simulation of areas of prognosis for short and medium term, that is, 5, 10 and 15 years.

Keywords: Urban expansion. Simulation of scenarios. Cellular automata.

\section{RESUMO}

A urbanização alavancou uma série de problemas nas cidades de médio e grande porte, resultado da falta de planejamento e de tecnologias para apoiar a tomada de decisões. Neste sentido, este trabalho tem como objetivo contribuir para a metodologia de modelagem por autômatos celulares, visando o estudo dos processos que condicionam a expansão da mancha urbana. Tendo como estudo de caso o município de Novo Hamburgo, RS. Para tanto foram utilizadas as manchas urbana de 1967, 1977, 1987, 1997, 2009 e 2015, totalizando uma análise histórica de 48 anos, além dos mapas temáticos: Declividades, Hipsométrico, Uso do Solo, Recursos Hídricos e Sistema Viário. Os dados compilados foram inseridos no ambiente da plataforma Dinamica EGO, que é um software livre que utiliza o sistema de Autômatos Celulares. 0 software, emprega um conjunto de mapas de entrada, composto por uma paisagem inicial, uma paisagem final e um compilado de variáveis temáticas que são combinadas a partir da definição de pesos de evidência visando gerar os mapas de probabilidade de transição. Os resultados apresentaram indices de similaridade superior 0,9 para as três primeiras modelagem 1977, 1987 e 1997, além de 0,83 para a simulação de 2015. Também foi possível analisar os fatores predominantes para cada processo de expansão, além da simulação de manchas de prognóstico para curto e médio prazo, ou seja 5, 10 e 15 anos.

Palavras-chave: Expansão urbana. Simulação de cenários. Autômatos celulares. 


\section{INTRODUCTION}

The quick process of urbanization of the cities promotes social and economic development, besides improving the quality of people lifes (UNITED NATIONS, 2012). However, an overly fast growth of the urban space is an aspect of extreme importance for the global change by its interaction with the ecosystem and the environment, creating adverse impacts in many scopes (ZHANG et al., 2016).

There is a need, therefore, for sustainable cities concerned with maximizing the positive effects of urban sprawl and reducing its negative effects to a minimum. Because of their impacts on the economy, human life and the environment, more researches on the subject are critical for the building of more sustainable cities and more consistent economies (ABIODUM, 2017).

Urbanization is the result of an unavoidable process of sequential transformation at a global level and has been a topic of great importance (FRANCO et al, 2017), especially in developing countries, for environmentalists and for public managers concerned about urban planning (YUAN 2005; GRIFFITHS et al., 2010). In general, the expansion of anthropic areas establishes a fundamental element in the change of the land use in much of the world, since the increase of the urban area occurs from the reduction of other environments, essentially of agricultural and field areas (JAEGER; SCHWICK, 2014). The modelling of changes in land use allows the construction of prognostic scenarios that minimize potential impacts and lead to adequate planning (VERBURG et al., 2008, VERBURG; OVERMARS 2009, TORRENS 2008, CHENG; MASSER 2004). However, trends information needs to be accurate so that they can be used in the development of new scenarios that assist in sustainable planning and development, as well as improving the quality of life in cities. (XIAN et al., 2005).

Understanding the changes in the environment through the years granted more importance to the obtainment of factors that influence such modifications, in this context, the model of Cellular Automata (CA) comes up (TRENTIN; FREITAS, 2010), based on the original concept from Ulan and Von Neumann in 1940, in order to understand the behavior os complex systems (MORENO et al., 2010).

One of the elements of the CA is the regular cell grid, which represents the current state of space, where each cell demonstrates the ability to support an activity, that is, a type of use and occupation of the land. In addition, other components are essential, such as: set of possible determinants of environmental changes, transition rules, influence of neighboring cells and time.

At each step of time, cells evolve according to the defined transition rule, geometry, as well as the influence of the neighborhood, taking into account the aspects of attraction or the spatial repulsiveness that one cell exerts on the other. Thus, CA models can reproduce realistic global behaviors and patterns from simple local interactions of individual cells, simulating prognostic scenarios, based on the extrapolation of the past changes (SOARES-FILHO et al., 2002; MORENO et al. 2010; LIU, 2008). 
There is a growing trend of using CA to simulate and predict complex geographic phenomena. There are modelling approaches that can be implemented through the CA concept. The models based on Dinamica EGO, for example, can be identified as auxiliary models, which allow for predictions using parametric and non-parametric approaches (BERBEROGLU et al., 2016).

Dynamic EGO is a model based on spatial simulation of CA that incorporates neighborhood-based transition algorithms and spatial feedback approaches in a multi-step stochastic simulation framework (MAEDA et al., 2010). This model comes from a method adapted from Agterberg and Bonham-Carter (1990) and Goodacre et al. (1993), which calculates intervals according to the data structure. It is a free software that employs a set of input maps, consisting of an initial landscape, a final landscape and a compiled thematic variables that are combined from the definition of weights of evidence aim to generate the transition probability maps (SOARES-FILHO et al., 2009).

The literature has several works based on cellular automata that use the Dynamic EGO software as a study tool. Wang et al. (2016) established a model that optimizes the conservation of ecosystems prioritizing strategic forest areas. Predictions of urban growth were made by Berberoglu et al. (2016) and Inouye (2015) also did so, combining these simulations with the characterization of the land use. Pathirana et al. (2013) related the land use in the urban expansion with the microclimatic changes and extreme precipitations. Simulations of past and future scenarios of expansions of rural activities as object of degradation of the natural biome were approached by Maeda et al. (2010). Stan et al. (2017) studied the influences of potential government interventions over land use. In addition, geospatial Technologies, such as remote sensing and the Geographic Information System (GIS), are extremely useful tools for new studies in terms of data collection, availability and processing capacity (MAEDA et al., 2010).

The urban areas in the municipality of Novo Hamburgo, RS are a reflection of the effects caused by the rapid growth of the population, such as frequent floods and large numbers of informal settlements. These problems are the result of the migratory process that took place in the municipality in the 1970s and 1980s, when the local economy achieved its greatest rise due to the industrialization of the shoemaking sector.

Such speed in the process of urban and industrial expansion in the municipality was not accompanied, however, by effective municipal planning, capable of predicting future scenarios and preparing the municipality for this growth, which may have occurred due to a lack of technological resources at the time, that could make such predictions with certain precision. With the availability and assistance of computational tools, such as those already mentioned, that give a greater degree of precision in simulations, it becomes possible to execute more consistent planning from modeling with greater accuracy. 
The objective of this work is to contribute to the CA methodology of modelling, aiming the study of processes which condition the expansion of the urban área, having as a study case the municipality of Novo Hamburgo, which went through rapid processes of urbanization from the 1970s, thus, this work aims to improve the understanding of the main conditioning factors for the growth of the anthropic area among the years of 1967 to 1977,1977 to 1987,1987 to 1997, 1997 to 2009 and 2009 to 2015, and thus to establish simulations of scenarios of short and term, five, ten and fifteen years, from the construction of the last urban area (2015).

\section{MATERIALS AND METHODS}

\subsection{DESCRIPTION OF THE STUDY AREA}

The study area comprehends the municipality of Novo Hamburgo (Figure 1), located on the metropolitan region of the state of Rio Grande do Sul, Brazil, under the coordinates $29^{\circ} 67^{\prime}$ Latitude South and $51^{\circ} 13^{\prime}$ Longitude West, $40 \mathrm{~km}$ away from the capital, Porto Alegre. It presents a territorial area of $224 \mathrm{~km}^{2}$, where $23,9 \%$ characterizes the urban area of the municipality (Riegel et al., 2017), with approximately 238.940 inhabitants (IBGE, 2010).

Figure 1 - Location of the study area
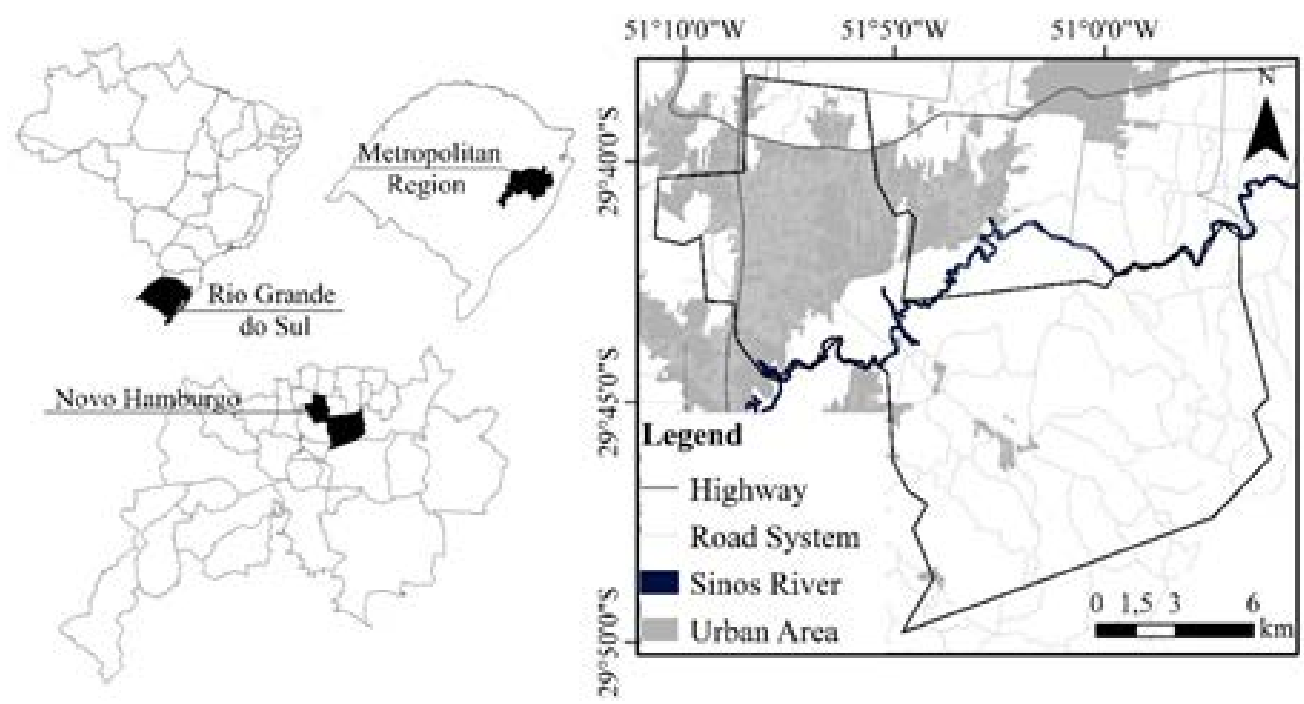

Source: authors 
The municipality was emancipated in 1927 and had its greatest economic and urban rise in the 1970s and 1980s, due to the growth and industrialization of the footwear shoe industry (Riegel and Quevedo 2015). Currently the northern portion of the municipality, located above the Sinos River, and between the BR 116 and RS 239 Highways, is highly occupied, with few possibilities for expansion. The areas adjacent to the main spot are considered APAs (Area of Environmental Protection) and APPs (Permanent Preservation Area), composed of Swamps and Areas Susceptible to Landslides and Flooding.

\subsection{MATERIALS}

- Vector Data - Limit of the municipality of Novo Hamburgo in projection UTM, Datum SAD 69 (IBGE, 2001); Urban Areas from the municipality, in the years 1967, 1977, 1987, 1997 and 2009 in projection UTM, Datum SAD 69 (RIEGEL; QUEVEDO, 2015); Map of Land Use and Occupation in the municipality in the year of 2015, in projection UTM, Datum WGS 84 (RIEGEL et al., 2017); Road System and Projection Drainage Network UTM, Datum SAD 69 (MONALISA PROJECT, 2005)

- Altimetry database - The system created by the Japan Ministry of Economy, Commerce and Industry (METI) and the National Aeronautics and Space Administration (NASA) of the United States of America, ASTER GDEM was used to obtain the model digital elevation study area (ASTER GDEM, 2011).

- Software - ArcGIS, version 10.2 for Windows (64-bit), software developed by ESRI for mapping and spatial reasoning, it allows you to explore and share location data (ESRI 2017). It was used in the preparation of spatial data; EGO Dynamics, version 4.0.3 for Windows (64-bit), free software developed by Soares et al. (2001) consists of a platform for the elaboration of dynamic, simple and complex spatial models, with multiple transitions interactions, dynamic feedbacks, simulations of space-time phenomena, among others. In this work it was used in the simulation of the urban scenarios and in the future prognoses.

\subsection{METHODS}

The Figure 2 shows a brief general vision of the modelling structure applied, which used an AC model developed by Soares Filho et al. (2001) inside the software Dinamica EGO, to analysis of land use dynamics. In a few words, the works is divided by 3 stages: a) Compilation and data organization; b) Modelling of transitions; c) Simulation and Validation. 
Figure 2 - Flow chart of the applied modelling

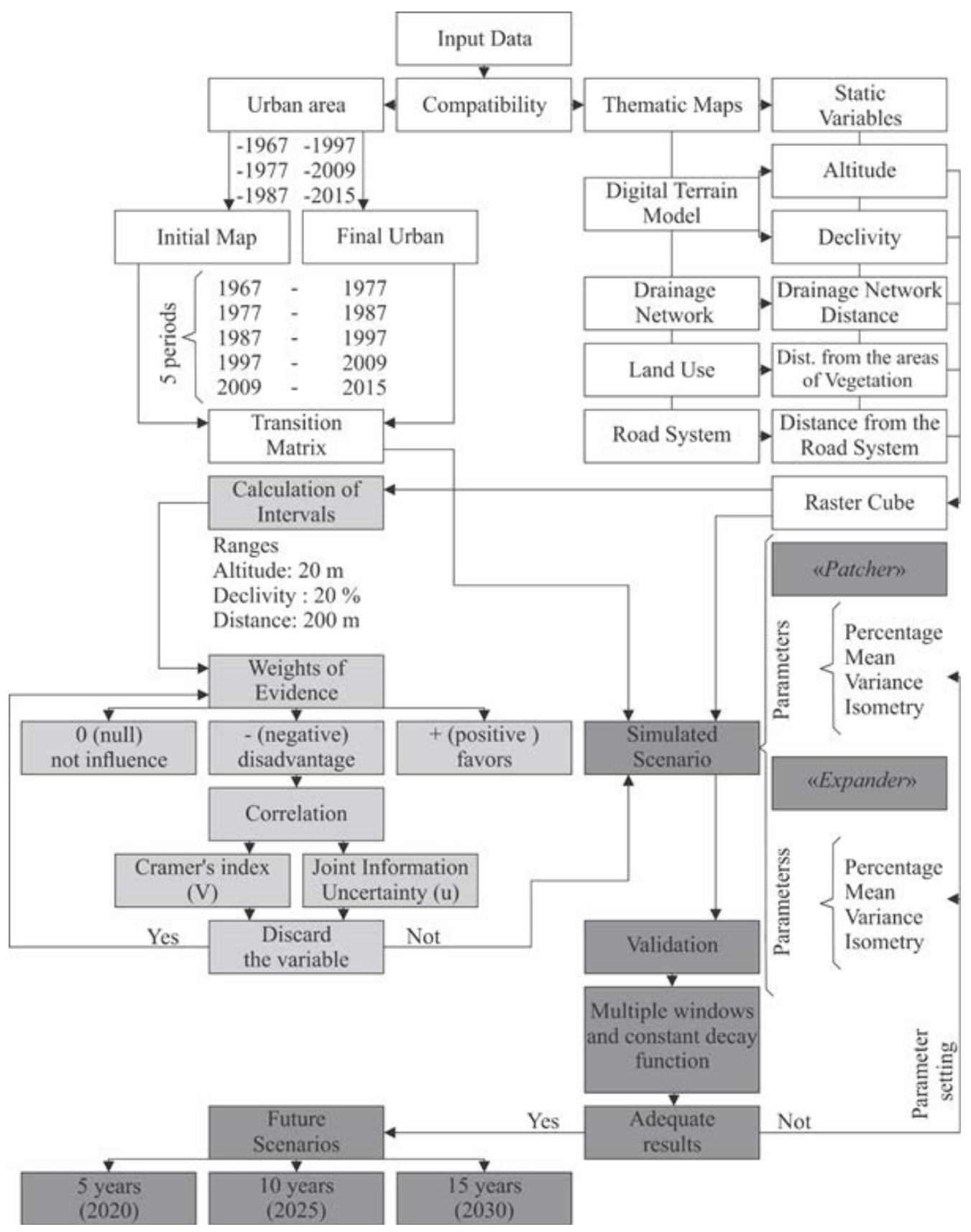

Source: Authors 


\section{a. Compilation and data organization}

Initially, the dynamic variables were compiled, elements that undergo alteration along the modelling, that is, the urban areas related to the years 1967, 1977, 1987, 1997, 2009 and the urban area of 2015, extracted from the map of land use and occupation. After the shapes were transformed to raster in the software ArcGIS with resolution 30×30m, coordinate system UTM and datum SAD 69, thus allowing the compatibility of the files.

For the set of static variables the map of the Drainage Network, the Road System, the Land Use and Occupancy and the Digital Terrain Model were compiled. For the vegetation map, the forest formation class established in the Land Use Map by Riegel et al. (2017). After that, the tool "Euclidean Distance" was used, in order to calculate the distance from the vegetation areas, the water resources and the road system, generating continuous raster images of the distance of each element. For the maps of altitudes and declivity, the Digital Terrain Model, employing the continuous symbology on both files, considering the same resolution and coordinate system used on previous files. The static variables were exported on "Tiff" format and then incorporated on the software Dinamica EGO, in which a construction of a raster cube was proceeded, a multilayer image that allows to join different maps.

The transition matrices corresponding to each simulation period were calculated in the Dinamica EGO Software from the beginning and end of each period. This procedure consists in creating a cross tabulation between two maps, specifying the time interval in each of the periods, generating two tables: "single step matrix" and "multiple step matrix" (Trentin and Freitas, 2010). The first analyzes the period as a whole and the second presents the steps of time per year, that is: Period 1 (1967 to 1977) 10 steps, Period 2 (1977 to 1987) 10 steps, Period 3 (1987 to 1997) 10 steps, Period 4 (1997 to 2009) 12 steps, Period 5 (2009 to 2015) 6 steps.

\section{b. Modelling of transitions}

The Calibration of the model is intended to select the best set of variables, in order to produce the adjustments between the empirical data and the observed reality (Rossetti, 2011). Thus, adjustment tests were carried out in order to provide the greatest similarities between the real scenario of the urban area and the simulated scenario for each period. This analysis allowed to separate the variables that really influenced the transitions of urban expansion, from those that were only noises. Therefore, the first procedure was to calculate the raster cube ranges for each continuous variable and the initial dynamic variable for each period, that is, to establish ranges of amplitude. The variables related to the distance of some element, obtained the delimited bands every 200 meters (drainage network $=0$ to 1.456 , 
vegetation $=0$ to $2838 \mathrm{~m}$, road system $=0$ to 1,753$)$, already the altitude variable was categorized every $20 \mathrm{~m}$ (altitude $=4$ to $335 \mathrm{~m}$ ) and finally the declivity map had its ranges established every $20 \%$ (declivity $=0$ to $126 \%$ ).

With the intervals defined, the initial and final urban area maps of each simulation, and the raster cube, it was possible to determine the weights of evidence, which produced an output file in the Dinamica EGO software. These weights determined whether or not the thematic variable influenced the transition of the urban area in that period. Thus, when there are negative weights, it means that the characteristic does not favor the occurrence of transition; positive weights tend to favor it; and weights equal to zero do not represent any type of influence (TRENTIN; FREITAS, 2010).

Cramer's index calculations (V) and the Joint Information Uncertainty (U) were used to evaluate the spatial dependence between the variables for the simulation periods (Rossetti, 2011). Thus, the model provided the correlation between the pairs of variables considered in each period. In all cases, no variables showed significant dependence, taking into account the work of Bonham-Carter (1994), who reports that values lower than 0.5 for these analyzes suggest that the dependence is low enough to maintain the variables in the model. Therefore, all the variables that had influence on the transitions were used to run the same.

\section{c. Simulation and Validation}

For the simulation of the expansion of the urban spot were used the initial map of each period, the raster cube and the weights of evidence. Two types of transition algorithms are incorporated into the Dinamica EGO software: the "expander" (expansion) function, which is linked to the expansion of existing urban areas; and the "patcher" function, referring to the formation of new urban areas (SOARES et al., 2007; SILVA et al., 2017 ROSSETTI, 2011).

The formation of these two types of algorithms depended on some statistical parameters, mean and variance, initially they were calculated from the area of transition polygons of each period, with the support of ArcGIS software. However, due to the exorbitant values of mean and variance it was not possible to use the real value, making it necessary to calibrate the value from validation tests. In addition to the statistical values, the software incorporates an isometry value and a percentage index. The first one establishes an aggregation index of the areas, whose variation is from zero (0) to two (2), which varies on a scale, the greater the value the greater the compaction of the spots (TRENTIN; FREITAS, 2010). In the case of this work, the value 1.7 was opted, which corresponds to a high compression, mainly due to the scale of the same that covers a municipal area. These values are responsible for multiplying the 
neighboring cells in order to determine the probability or otherwise of the urban occupation in a specific period. The second value establishes the percentage of area that will expand by the method "Expander" and "Patcher". In this case, the values were calculated in ArcGIS, separating the new urban cores from the existing areas, and the insertion in the Dinamica EGO software was rounded. These parameters were changed and tested in order to obtain the most appropriate model for each period.

In general, spatial models need to be validated within a neighborhood context, which takes into account the adjacent cells, since even if a simulated cell does not correspond exactly to a real cell, the maps may still have patterns of similarity (SOARES FILHO et al., 2009). Thus, the validation was performed by analyzing the "fuzzy" similarity between the simulated map and the map for the same year, an adaptation of the index developed by Hangen (2003) within the software Dinamica EGO. The method uses multiple windows and constant decay function (SOARES FILHO et al., 2009), the results vary from 0 to 1, and the closer to 1 the greater the similarity between the maps. In this case a simulated cell is compared to the corresponding cell in the real map, and to a lesser extent by neighboring cells, in different window sizes (SOARES FILHO et al., 2009). The study presents the similarity values in the $3 \times 3$, $7 \times 7$ and $11 \times 11$ windows for each analyzed period.

Based on the parameters and weights used in the simulation of the last period (2009 to 2015), the model for future forecasts was carried out, considering the period of 5 (2020), 10 (2025) and 15 years (2030), having as initial map the spot of 2015.

\section{RESULTS AND DISCUSSION}

Table 1 presents the areas related to the urban areas of each period with the percentage relative to the total area and the respective number of cells, in a resolution $30 \times 30 \mathrm{~m}$. At the same time, it is observed that the urban area occupies approximately $23.88 \%$ of the total area of the municipality, since there is a large rural zone. The urban environmental problems in the municipality of Novo Hamburgo are vast, precisely due to the position of the main urban area bounded by RS 239, BR 116 and Rio dos Sinos. The current zone is highly densified, with practically no possibility of expansion in its location, considering the existence of APAS, APP, risk areas and wetlands in the adjacent regions. 
Table 1 - Table of the area of the urban zone of 1967, 1977, 1987, 1997, 2009 e 2015

\begin{tabular}{ccccc}
\hline Urban Area & Number of Cells & Area (ha) & Percentage (\%) \\
\hline 1967 & 30474 & 2742,66 & 12,36 \\
1977 & 37710 & 3393,9 & 15,29 \\
1987 & 45718 & 4114,62 & 18,54 \\
1997 & 52574 & 4731,66 & 21,32 \\
2009 & 54906 & 4941,54 & 22,26 \\
2015 & 58909 & 5301,81 & 23,88 \\
\hline
\end{tabular}

\section{Source: Authors}

The periods of greatest rise of urban expansion occurred among the 70s, $80 \mathrm{~s}$ and $90 \mathrm{~s}$, due to the historical characteristics of the municipality and the employment opportunities arising from the footwear shoe sector. It is also observed that most of the occupation of the risk areas occurred between 1987 and 1997, when the main urban zone practically reaches its current limits, and exhausts the possibilities of adequate occupation in its proximities (Riegel and Quevedo, 2015). In Table 2, there is still a change in the expansion process, which since 1987 assumes the formation of new urban core ("Patcher"), often far from the main set. The Simple Transition Matrix presents the percentages of transitions used to simulate each model, in which the relatively high value of the last transition. 


\section{CONHECIMENTO

Table 2 - Table of transition areas of the urban zones

\begin{tabular}{cccc|c|c|c}
\hline Transition & Number of Pixels & Area (ha) & Expander (\%) & Patcher (\%) & Simple Transition Matrix \\
\hline $1967-1977$ & 7236 & 651,24 & $100 \%$ & - & $0,339 \%$ \\
$1977-1987$ & 8008 & 720,72 & $100 \%$ & - & $0,390 \%$ \\
$1987-1997$ & 6856 & 617,04 & $68 \%$ & $32 \%$ & $0,346 \%$ \\
$1997-2009$ & 2332 & 209,88 & $38 \%$ & $62 \%$ & $0,100 \%$ \\
$2009-2015$ & 4003 & 360,27 & $60 \%$ & $40 \%$ & $0,351 \%$ \\
\hline
\end{tabular}

Source: Authors 


\section{CONHECIMENTO ONLINE}

For the design of the 5 models, 5 continuous variables were used: Altitude ( 4 to $335 \mathrm{~m}$ ), Declivity (0 to $126 \%$ ), Drainage Network Distance (0 to $1456 \mathrm{~m}$ ), Vegetation Distance (0 to $2838 \mathrm{~m}$ ) Road (0 to $1753 \mathrm{~m})$, according to Figure 3.

Figure 3 - Continuous Variables
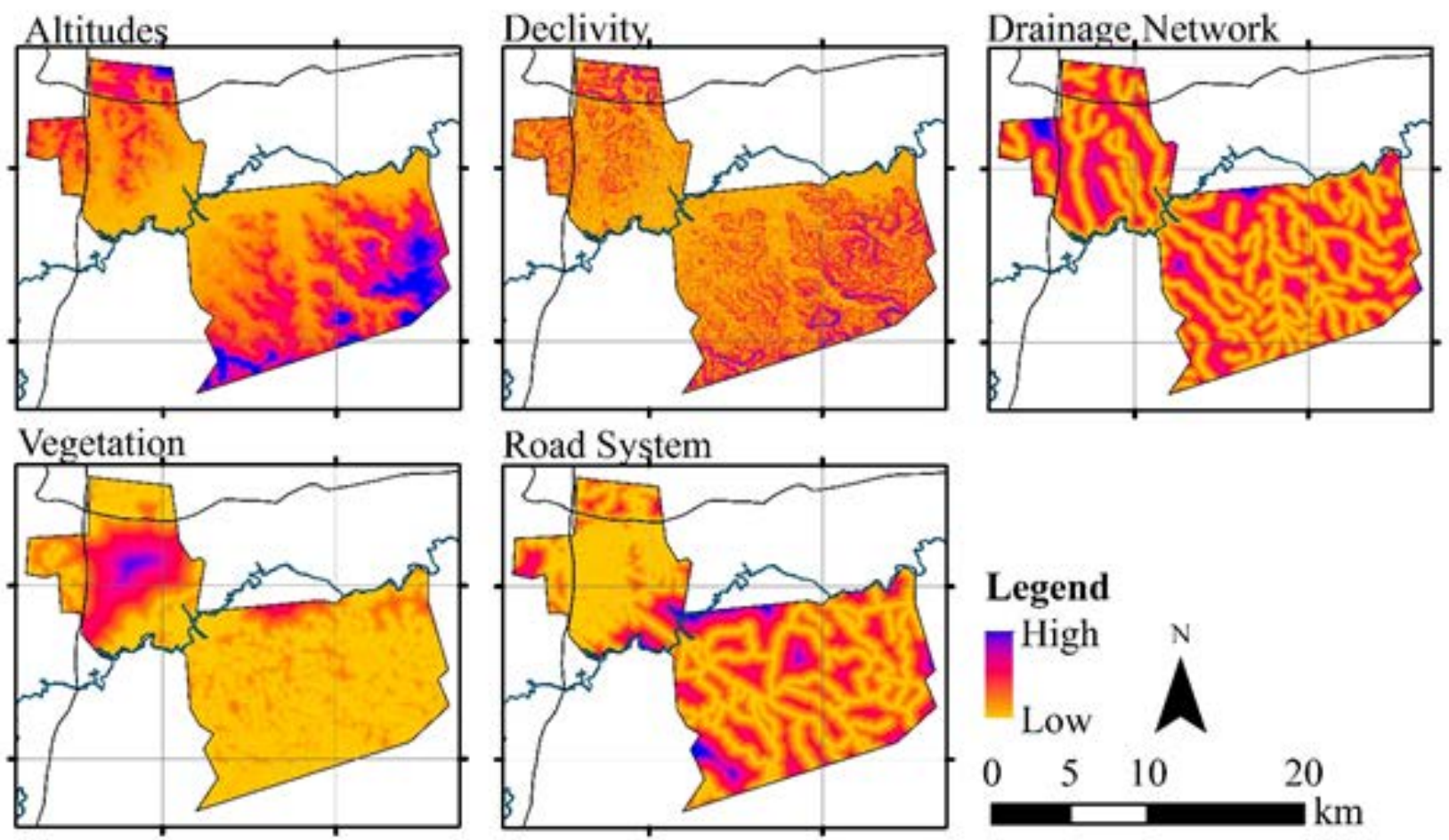

Source: Authors

Throughout the analyzed periods, it was possible to verify the factors that influenced the transitions of the urban areas. Chart 1 shows the maximum weights responsible for each transition period. Between 1967 and 1977, all the factors behaved in a similar way, with the exception of the altitude that obtained low weights and consequently did not have relation with the urban expansion. In the simulations of 1987 and 1997, the altitude was the variable that most showed influence in the expansion, in this last year also highlights the disappearance of the distance factor of the drainage network, a consequence also visualized in the following simulations. The highest values in the Chart correspond to the variable altitude in 1997 and the distance of the road system in 2015, with the weights $-5,488$ and $-5,305$ respectively. 


\section{Chart 1 - Graph of the maximum weights of influence of urban area transitions}

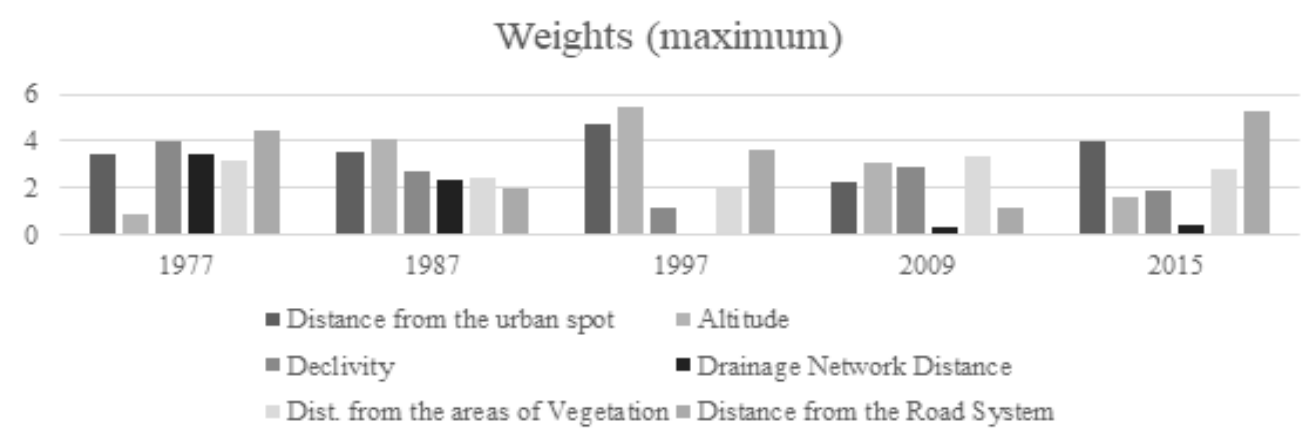

Source: Authors

The values incorporated between mean and variance were similar in all simulations according to Table 3, and the variations occurred in the percentage of areas that would be expanded by the "expander" and "patcher" method. These variations took into consideration what is presented in Table 2. At this moment, it is important to note that the area of each pixel corresponds to $30 \times 30 \mathrm{~m}$, that is, 900 square meters. Thus, expansion by the "expander" method would only occur when 22 pixels were conducive to transition, and in the "patcher" format it would take 11 pixels to form a new core.

Table 3 - Values used in the simulation processes

\begin{tabular}{c|c|c|c|c|c|c|c}
\hline \multirow{2}{*}{ Transition Areas } & \multicolumn{2}{|c|}{ Expander } & $(\%)$ & \multicolumn{2}{|c|}{ Patcher } & $(\%)$ & \\
\cline { 2 - 8 } & Mean (ha) & Variance (ha) & & Mean (ha) & Variance (ha) & & Isometry \\
\hline $\mathbf{1 9 6 7 - 1 9 7 7}$ & 2 & 4 & 100 & - & - & - & 1,7 \\
$1977-1987$ & 2 & 4 & 100 & - & - & - & 1,7 \\
$1987-1997$ & 2 & 4 & 70 & 1 & 2 & 30 & 1,7 \\
$1997-2009$ & 2 & 4 & 40 & 1 & 2 & 60 & 1,7 \\
$\mathbf{2 0 0 9}-\mathbf{2 0 1 5}$ & 2 & 4 & 60 & 1 & 2 & 40 & 1,7 \\
\hline
\end{tabular}

Source: Authors

Figure 4 presents the results of the simulations performed in each period, as well as the comparative area of each analysis. The first three simulations present satisfactory results, mainly due to the fact that the expansion occurs largely in the main zone, making the simulation process easier. Already in 2009 and 2015, a great amount of new urban cores is observed in the rural zone of the municipality, which hinders the simulation process. This process is the result of a highly consolidated urban territory with few growth options, due to the natural barriers that are fomented in its adjacent areas. 
Figure 4 - Maps of the real and simulated urban area of each period of the analysis
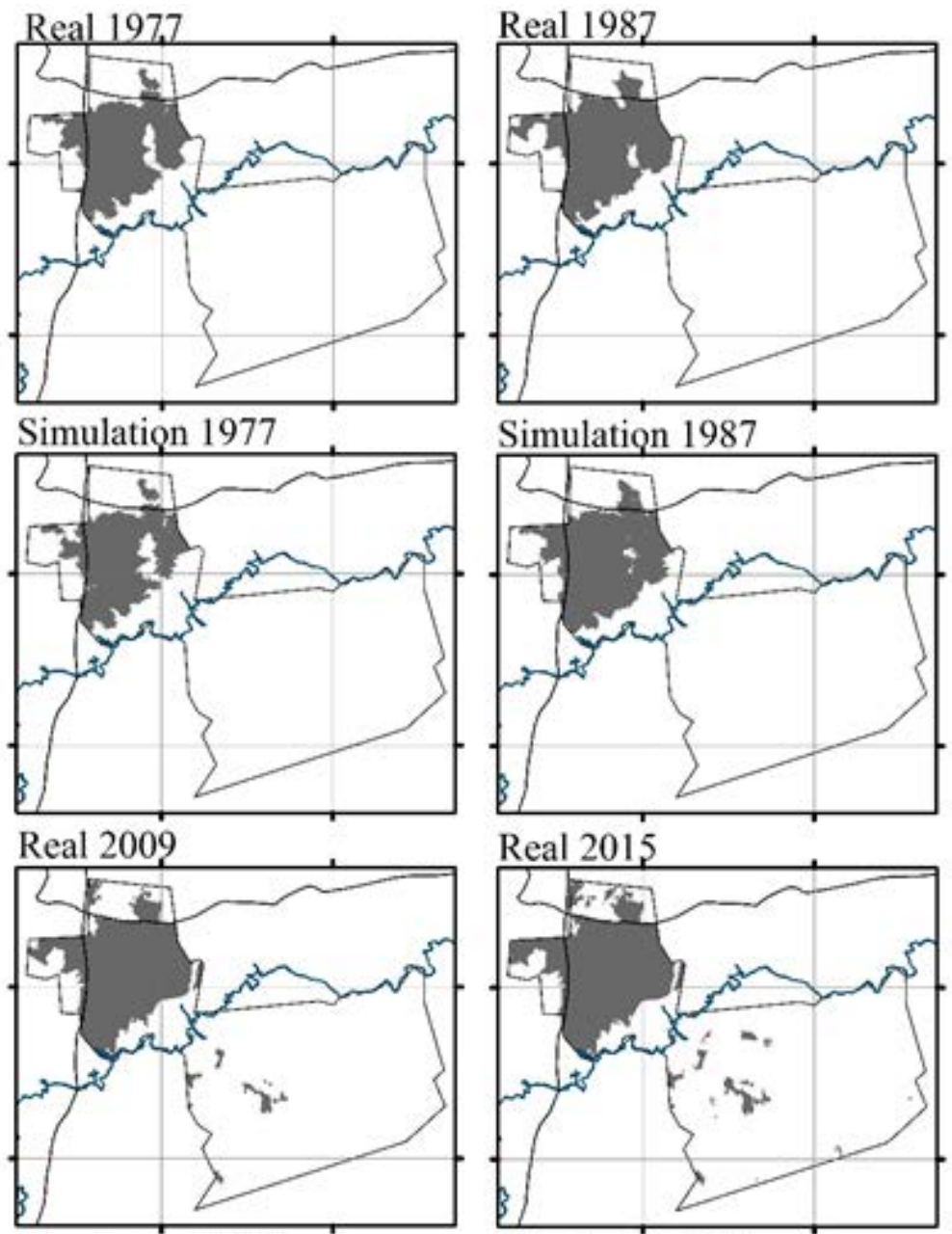

Simulation 2009
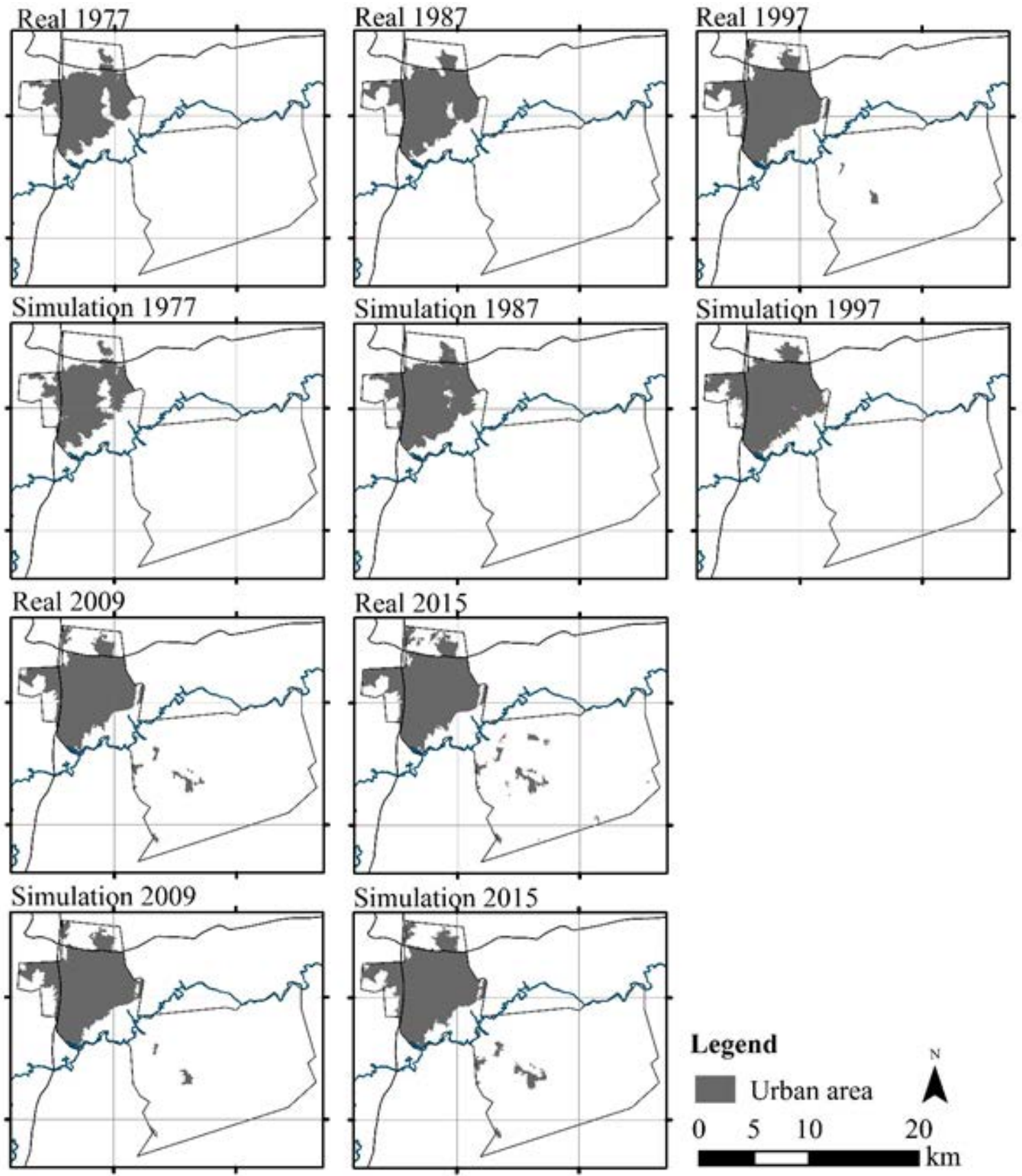

Legend

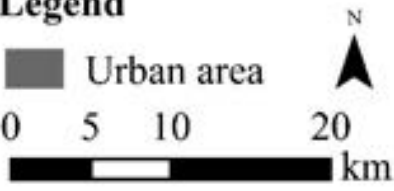

Source: Authors 
Table 4 presents the similarity values of each map, using the "fuzzy" similarity technique, and constant decay function, in three window sizes: $3 \times 3 ; 7 \times 7 ; 11 \times 11$. It is observed a growth from the size of the window, with similarities that vary between minimum and maximum. The maximum values obtained in the first periods of analysis correspond to $0.941,0.945$ and 0.906 respectively, that is, they are values with potential correctness in their simulations. In the 2009 simulation process, the value obtained did not exceed 0.533 similarity, which is due to the long simulation period of 12 years, higher than the other analyzes, and mainly the formation of new cores in the rural area, which corresponded to $62 \%$ of the area expanded in this period. It is believed that the determining factors for the expansion in this period were not efficient as in the other simulation processes, or even the absence of a pattern in the formation of these cores, through the casual appearance of these new areas. Refined processes such as analysis of intermediate images over this period could improve results. In the following period, which varies from 2009 to 2015, there is a remarkable increase in similarity, due to the drop in the percentage of area for the formation of new areas $(40 \%)$, that is, there were more growths of existing spots than new areas with residential occupation. Even so, the largest transition area occurred in the rural area. 
Table 4 - Evaluation of urban area simulations

\begin{tabular}{ccccc}
\hline Period of the simulation & Windows (pixels) & Minimum & Maximum \\
\hline \multirow{2}{*}{$1967-\mathbf{1 9 7 7}$} & $3 \times 3$ & 0.592 & 0.699 \\
& $7 \times 7$ & 0.689 & 0.86 \\
$1977-\mathbf{1 9 8 7}$ & $11 \times 11$ & 0.752 & 0.941 \\
& $3 \times 3$ & 0.679 & 0.687 \\
& $7 \times 7$ & 0.786 & 0.846 \\
$\mathbf{1 9 8 7 - 1 9 9 7}$ & $11 \times 11$ & 0.835 & 0.945 \\
& $3 \times 3$ & 0.598 & 0.631 \\
& $7 \times 7$ & 0.661 & 0.812 \\
$\mathbf{1 9 9 7 - 2 0 0 9}$ & $11 \times 11$ & 0.697 & 0.906 \\
& $3 \times 3$ & 0.211 & 0.217 \\
& $7 \times 7$ & 0.293 & 0.374 \\
$\mathbf{2 0 0 9 - 2 0 1 5}$ & $11 \times 11$ & 0.355 & 0.533 \\
& $3 \times 3$ & 0.35 & 0.403 \\
& $7 \times 7$ & 0.481 & 0.666 \\
& $11 \times 11$ & 0.547 & 0.832 \\
\hline
\end{tabular}

Source: Authors

In a general context, the indexes of similarity were satisfactory when compared to other works: Macedo et al. (2013) reached a similarity value of 0.518 in the $11 \times 11$ window, in an analysis of the change in the soil cover of the city of Arealva (SP) between 2005 and 2010. Lima (2014) obtained values of 0.84 and 0.87 for an analysis of land use change in the Baixo Sinos region (RS) among 1990, 2000 and 2011; Silva et al. (2017) obtained values of 0.925 for analysis of the change of the vegetation cover of the micro region of the Western Campaign (RS) between 1996 and 2011; Benedetti (2010) obtained values higher than 0.99, analyzing the transformations of the forest cover of the Southeast Serra and the Southern Campaign (RS) between 2004 and 2008; Ferrari (2008) reached 0.842 analyzing the changes in soil cover 
of the Earth of the Fourth Colony (RS), between 2002 and 2008; Kawashima et al. (2016) reached 0.74 by analyzing the changes in the landscape of the port region of Baixada Santista (State of São Paulo) between 2005 and 2013; Rossetti (2011) obtained similarity indexes between 0.55 and 0.75 in a 9x9 window, analyzing the changes in urban land use in Rio Claro (SP) among 1972, 1988 and 2006.

\subsection{SIMULATION OF FUTURE PROGNOSTIC SCENARIOS}

Figure 5 shows the results from the simulation of the future prediction scenarios, the urban areas for the years 2020, 2025 and 2030. In this case, the parameters used in the simulations of the last analysis period (2009-2015). In general, growth is concentrated in rural areas, through the expansion of existing spots and the formation of two cores, designed in the simulation of 2020 and 2025 respectively. The highly densified territory in the urban region does not allow for large expanses, but the subtlest expansion is visible towards areas of flooding, landslide and wetland, probably due to the large irregular areas in these areas. These processes raise concerns about planning and monitoring in inappropriate municipalities. The rural area also needs eminent care, given the rich local environmental patrimony, which affects crops and field areas, which can be affected by the lack of infrastructure mainly related to the basic sanitation aspects of the residents who settle in these regions. 
Figure 5 - Maps of urban and simulated areas for each period of analysis
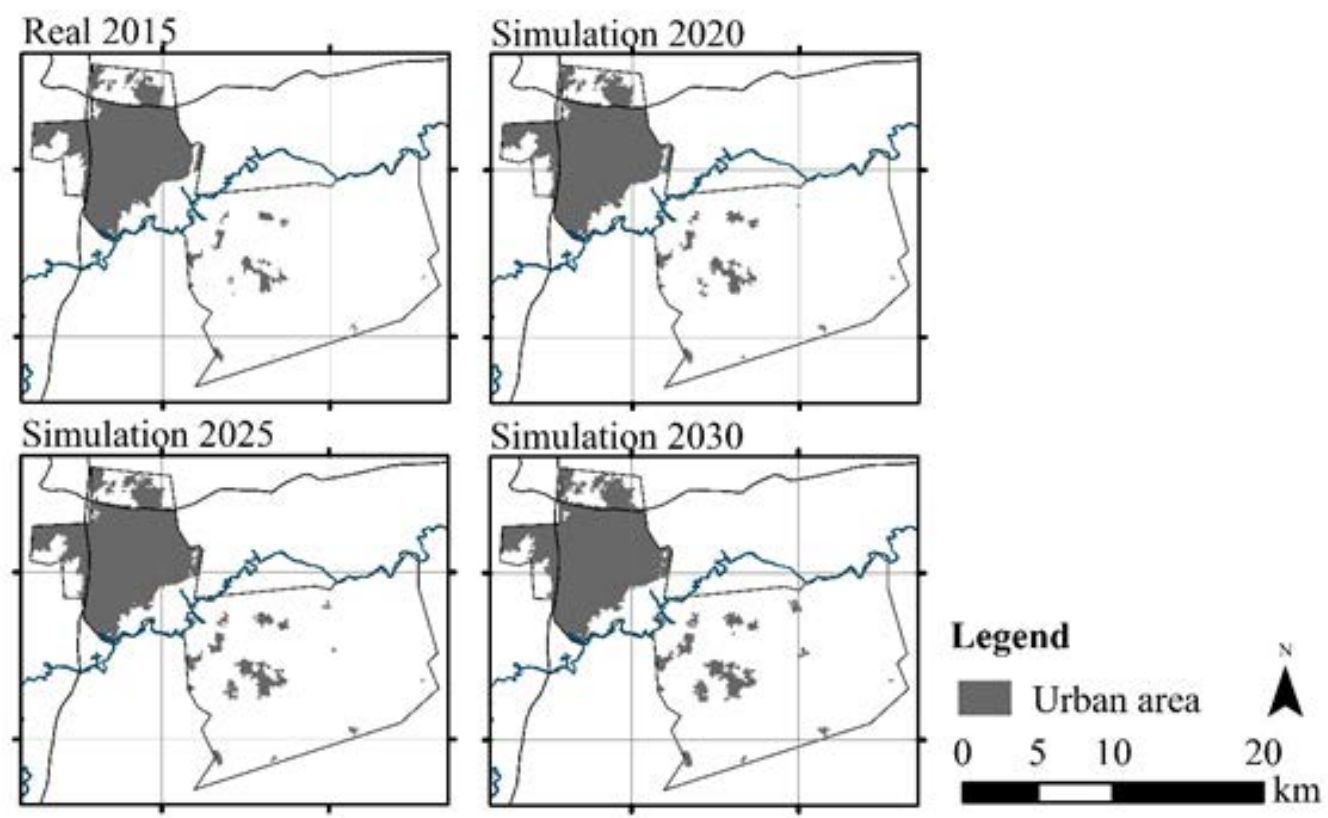

Source: Authors

The urban expansion of the municipality is around $1 \%$ every five years, a smaller growth, compared to $1977(2.93 \%), 1987(3.25 \%)$ and $1997(2.78 \%)$, but higher than growth, which in the last census (2010), was $0.84 \%$.

Table 5 - Prognosis of Expansion Areas

\begin{tabular}{l|l|l|l}
\hline Urban Area (simulates) & Number of cells & Area (ha) & Percentage (\%) \\
\hline 2020 & 62176 & 5595.84 & 25.20 \\
2025 & 65386 & 5884.74 & 26.51 \\
2030 & 68540 & 6168.6 & 27.78 \\
\hline
\end{tabular}

Source: Authors 
It should be noted that for this growth to occur, it will be necessary to reduce rural environments and vegetation, which are very important for the maintenance of our ecosystems. Thus, the greater the care with planning of these expanding areas, the less will be the effects on the environment. Ensuring permeability, integrating infrastructure services, securing adequate land parceling, controlling occupancy rates and establishing green areas are some of the strategies needed to ensure that future occupancy processes do not maximize existing problems or create new impacts on as in past generations.

\section{FINAL CONSIDERATIONS}

This work has relevance to the study area, since it presents the first urban growth modeling study for the municipality of Novo Hamburgo, analyzing the historical factors that influenced the transition of urban areas, in addition to the short and medium term projections. The study also allows the adoption of the method for other regions, in addition to comparisons with similar municipalities, allowing future analyzes on the same area of study. Therefore, it was identified that factors such as the distance from the drainage network were significant for accommodation of urban occupation in the period between 1967 and 1987, and are no longer relevant in future analyzes; aspects such as distance from the existing urban spot and vegetation, are also variables present in all periods of expansion; however, it should be noted that the aspects with the greatest influence were the altitude in 1997 and the distance from the road system in 2015.

Simulation processes also obtained satisfactory similarity indexes for almost every year, surpassing 0.9 of similarity in the 1977, 1987 and 1997 simulations, and 0.83 for the simulation of 2015. However, the simulation between the period of 1997 and 2009 was evidently out of date, with a maximum value of 0.53 , mainly due to the fact that the expansion of this period occurs more intensively on the form of new cores. Based on the last simulation (2015), the parameters were used for future prognoses at 5, 10 and 15 years. The simulated spots showed a considerable increase of the urban areas located in the rural area of the municipality, evidencing the need for planning and installation of basic infrastructures. Currently this region is devoid of piped water and sewage network, resulting in the drilling of wells, often irregular and in the inadequate disposal of sewage.

In the urban area, there is also evident the growth of the existing zone, but due to the lack of suitable areas for occupation, an imposition of expansion in front of areas of risk such as floods and landslides, preservation areas and plots is established, establishing the aggravation of historical problems in the region. In this way, it is emphasized the need to inspect these areas, in order to control illegal progress and to allow the sustainable use of the soil. The analysis also made evident the need for the care of 
soil use, even if the growth of the urban spot is less expressive than in other historical periods, with an increase of $1 \%$ of the territorial area every 5 years, that is, many of municipal problems are already consolidated and progress without planning can aggravate these factors.

As a future proposal, it aims to establish an environmental urban zoning, with a focus on the quality of the environment, that allows anthropic actions to consolidate without maximizing social and environmental problems, seeking solutions for urban and natural environment relations.

\section{REFERENCES}

ABIODUN, O. E., OLALEYE, J. B., OLUSINA, J. O., and OMOGUNLOYE, O. G. The pattern and drivers of urban expansion in greater Lagos from 1984 to 2006. J. Environ. Sci. Res. Manage., n. 7, v. 2, p. 32-45, 2015.

BONHAM-CARTER, G. Geographic information systems for geoscientists: modelling with GIS. New York: Pergamon, 1994.

CHENG, J., \& MASSER, I. Understanding spatial and temporal processes of urban growth: cellular automata modelling. Environment and Planning B: Planning and Design, v. 31, n. 2, p. 167-194, 2004.

ESRI. Work Smarter With ArcGIS. 2017. Available at: <http://www.esri.com/arcgis/about-arcgis>.

FRANCO, S. Ph.D.; MANDLA, V. R., Ph.D.; RAO, K. R. M., Ph.D. Trajectory of Urban Growth and Its Socioeconomic Impact on a Rapidly Emerging Megacity. Journal of Urban Planning and Development, v. 143, n. 3, 2017.

GRIFFITHS, P., HOSTERT, P., GRUEBNER, O., \& van der LINDEN, S. Mapping megacity growth with multisensor data. Remote Sensing of Environment, v. 114, n. 2, p. 426-439, 2010.

HAGEN, A., 2003. Fuzzy set approach to assessing similarity of categorical maps. International Journal of Geographical Information Science, v. 17, n. 3, p. 235-249.

IBGE. Cidades @ Novo Hamburgo. 2010. Available at: <http://www.ibge.gov.br/cidadesat/painel/painel. php?codmun=431340 >. 
JAEGER, J. A.; SCHWICK, C. Improving the measurement of urban sprawl: Weighted Urban Proliferation (WUP) and its application to Switzerland. Ecological Indicators, v. 38, p. 294-308, 2014.

LIU, Y. Modelling urban development with geographical information systems and cellular automata. CRC Press, p. 188, 2008.

MORENO, N., WANG, F., \& MARCEAU, D. J. A geographic object-based approach in cellular automata modeling. Photogrammetric Engineering \& Remote Sensing, v. 76, n. 2, p. 183-191, 2010.

RIEGEL, R. P.; QUEVEDO, D. M. de. Uso de geotecnologias na análise das áreas de risco do município de Novo Hamburgo e a relação do risco com a evolução urbana. in: LADWIG, H. S., SCHWALM, H. (Orgs.), Planejamento e Gestão territorial: Experiências Sustentáveis, ed. Insular, Florianópolis, p. 9 -34, 2015.

RIEGEL, R. P.; ALVES, D. D.; ROQUE, D. C.; RODRIGUES, M. A. S.; QUEVEDO, D. M. Método Híbrido de Classificação do Uso do Solo, como subsídio para a construção de um Zoneamento Urbano Ambiental In: Seminário de Pós Graduação da Universidade Feevale, 10., 2017, Novo Hamburgo. Anais... Novo Hamburgo: Feevale, 2018.

ROSSETTI, L. A. F. G. Modelagem Dinâmica Espacial de Mudanças no Uso do Solo Urbano: Contribuição Metodológica. Rio Claro, SP. Tese de Doutorado, Universidade Estadual Paulista Júlio de Mesquita Filho, 2011, 132 p., 2010.

TRENTIN, G.; de FREITAS, M. I. C. Modelagem da dinâmica espacial urbana: modelo de autômato celular na simulação de cenários para o município de Americana-SP. Revista Brasileira de Cartografia, v. 62, 2010.

TORRENS, P. M. Simulating sprawl. Annals of the Association of American Geographers, v. 96, n. 2, p. 248-275, 2006.

SILVA, E. A.; TRAMONTINA, J.; ALBA, E.; GOERGEN, L. C. D. G.; FINGER, A. P.; PEREIRA, R. S. Forest Cover Analysis Through the Weights of Evidence Method in the Campanha Ocidental Region-RS (Brazil).

Revista Árvore, v. 41, n. 1, 2017.

SOARES-FILHO, B. S.; ASSUNÇÃO, R. M.; PANTUZZO, A. E. Modeling the Spatial Transition Probabilities of Landscape Dynamics in an Amazonian Colonization Frontier: Transition probability maps indicate where changes may occur in the landscape, thus enabling better evaluation of the ecological consequences of landscape evolution. AIBS Bulletin, v. 51, n. 12, p. 1059-1067, 2001.

SOARES-FILHO, B. S., CERQUEIRA, G. C., \& PENNACHIN, C. L. DINAMICA—a stochastic cellular 
automata model designed to simulate the landscape dynamics in an Amazonian colonization frontier. Ecological modelling, v. 154, n. 3, p. 217-235, 2002.

SOARES-FILHO, B.S.; RODRIGUES, H.O.; COSTA, W.L.S. Modeling Environmental Dynamics with Dinamica EGO. 2009. Available at: <http://www.csr.ufmg.br/dinamica/>

UNITED NATIONS. World urbanization prospects: The 2011 revision. 2012. Available at: <http://esa. un.org/unpd/wup/index/htm>

VERBURG, P. H.; EICKHOUT, B.; van MEIJL, H. A multi-scale, multi-model approach for analyzing the future dynamics of European land use. The annals of regional science, v. 42, n. 1, p. 57-77, 2008.

VERBURG, P. H.,; OVERMARS, K. P. Combining top-down and bottom-up dynamics in land use modeling: exploring the future of abandoned farmlands in Europe with the Dyna-CLUE model. Landscape ecology, v. 24, n. 9, p. 1167, 2009.

ZHANG, X.; BAI, Z.; FAN, X.; LU, Y.; CAO, Y.; ZHAO, Z.; SUN, Q.; PAN, J. Urban Expansion Process, Pattern, and Land Use Response in an Urban Mining Composited Zone from 1986 to 2013. Journal of Urban Planning and Development, v. 142, n. 4, 2016. 